\title{
Eddy Current Flaw Testing Probe With High Performance in Detecting Flaws During In-service Inspection of Tubing
}

\author{
Kiyoshi Koyama Member (Nihon University, koyama@cit.nihon-u.ac.jp) \\ Hiroshi Hoshikawa Member (Nihon University, hhoshi@cit.nihon-u.ac.jp)
}

Keywords: nondestructive testing, eddy current testing, tubing inspection, inner probe, support noise

\section{Introduction}

Eddy current nondestructive flaw testing (ECT) is widely used for product inspection. In the inspection of heat exchanger tubing in power plant and chemical plants, ECT is performed by using an inner probe, because of the structural restrictions of such plants. However, high levels of wobble noise and support plate noise occurs in the conventional method using a rotating pancake coil. The authors therefore propose new minimal noise eddy current inner probes. Tow new types of probes have been developed: one for detecting axial flaws, and the other for detecting circumference flaws. These probes can detect flaws with a low level of noise. The phase of the flaw signal by the new probes changes according to the flaw depth. As a result, the signal phase by the new probes can be used for evaluating the depth of surface flaws.

\section{New Eddy Current Probe}

Figure 1 shows the new eddy current probe for detection of axial flaws. Tow exciting coils winding to the circumferential direction induces eddy current in the tubing material parallel to themselves. The small detecting tangential coil arranged between two exciting coils pick up only the parallel component of the eddy current to itself.

When the tube has no surface flaw as shown in Figure 2(a), the detecting coil generate no signal because the eddy current has no parallel component to it. When there is a surface flaw disturbing the eddy current, some of the eddy current circulates parallel to the flaw and detecting coil as shown in Figure 2(b). The detecting coil generate flaw signal. When the probe is located under the support plate as shown in Figure 2(c), the detecting coil generate no signal because the eddy current has no parallel component to the detecting coil. Thus the new probe dose not generates wobble noise and support plate noise.

\section{Experimental Results}

Figure 3 shows the flaw signal and support plate noises when the

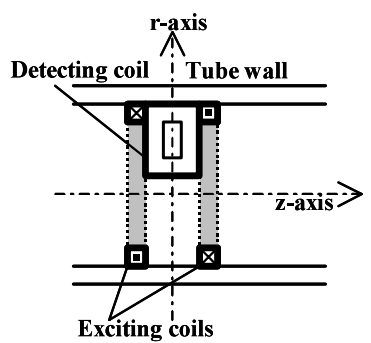

(a) Front view

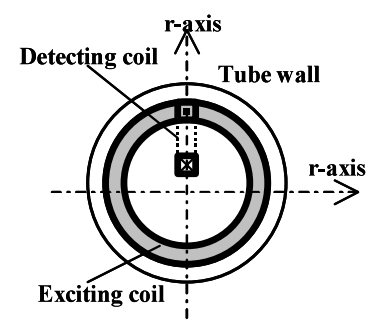

(b) Side view
Fig. 1. New eddy current probe probe scans around support plate with axial flaw of $0.9 \mathrm{~mm}$ depth. The figure indicates that the probe clearly detects the flaw without much interference from the wobble noise and support plate noise.

From the result of the flaw signal patterns, the authors derived the flaw depth evaluation curve based on the signal phase as shown in Figure 4 . Thus flaw depth can be evaluated by applying flaw signal phase.

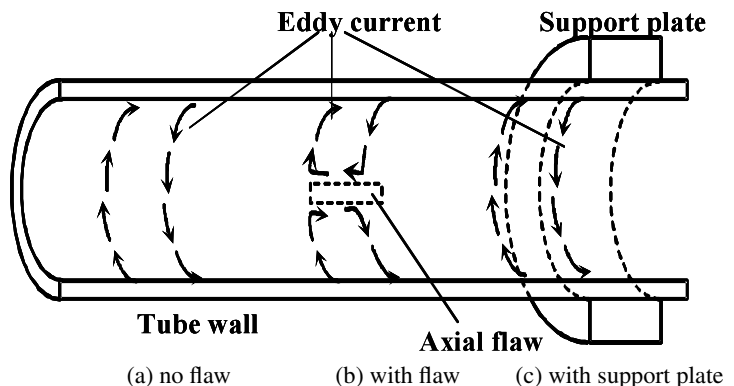

Fig. 2. Principle of flaw detection

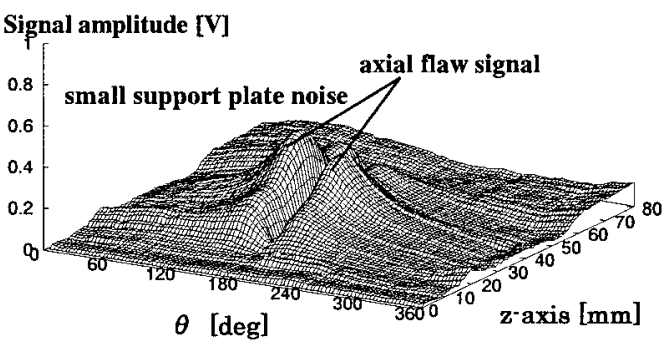

Flaw : depth $60 \%$, length $15 \mathrm{~mm}$, width $0.5 \mathrm{~mm}$

Fig. 3. Flaw signal scanning the axial flaw under support plate

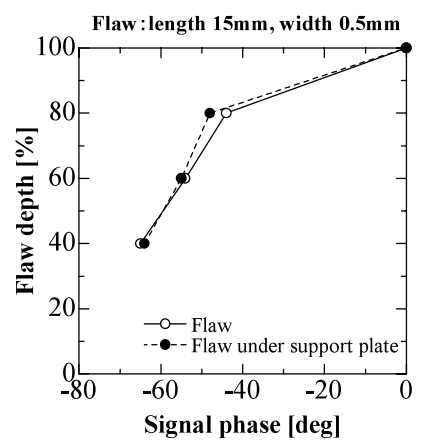

Fig. 4. Flaw signal phase vs. flaw depth 


\title{
熱交換器細管の保守検査における きず検出性能の高い渦電流探傷プローブ
}

\author{
正 員 小山潔* 正員 星川 洋* \\ Eddy Current Flaw Testing Probe with High Performance in Detecting Flaws \\ during In-Service Inspection of Tubing
}

Kiyoshi Koyama*, Member, Hiroshi Hoshikawa*, Member

\begin{abstract}
Eddy current flaw testing that uses changes in the impedance of the test coil as the electromagnetic field interacts with the test material is a non-destructive testing method. It can be used to inspect test material at high speed without bringing the test coil into contact with the test material. Therefore, it is widely used for product inspection. In the inspection of heat exchanger tubing in power plants and chemical plants, eddy current flaw testing is performed by using an inner probe, because of the structural restrictions of such plants. However, high levels of wobble noise and support plate noise occur in the conventional method using a rotating pancake coil. The authors therefore propose new minimal-noise eddy current inner probes. Two new types of probes have been developed: one for detecting axial flaws, and the other for detecting circumference flaws. These probes can detect flaws with a low level of noise. The phase of the flaw signal by the new probes changes according to the flaw depth. As a result, the signal phase by the new probes can be used for evaluating the depth of surface flaws.
\end{abstract}

キーワード : 非破壞試験, 渦電流試験, 管の保守検査, 内扫プローブ, 支持板雑音

Keywords: Nondestructive testing, Eddy current testing, Tubing inspection, Inner probe, Support plate noise

\section{1. はじめに}

発電所や化学プラントなどにおける熱交換器では，細管 が破損し管の内部から漏れ出る漏洩事故を未然に防ぐため に定期的な保守検査が行われている。熱交換器などの細管 の保守検査においては，数千本もの管を支えるための支持 板があり，その構造的な制約から管の内部に試験コイルを 挿入して検査を行う内挿プローブを用いた渦電流探傷試験 が適用されている。内挿プローブとしては，従来から渦電 流探傷試験で多用されているパンケーキ状の小さな円形コ イルを管の周方向に回転させ軸方向に移動させることを繰 返す回転走査を行うプローブなどが適用されている。しか し, 従来のプローブでは, プローブと試験導体との相対距離 の変化による雑音や管を支えるための支持板による雑音な どが発生する問題がある。このため，これらの雑音が探傷 の妨げとなり小さなきずの検出が困難である。したがって， 雑音を発生せずきず検出性能の高いプローブが求められて いる。近年では, プローブと試験導体との相対距離の変化

\footnotetext{
* 日本大学生産工学部電気電子工学科

干 275-8575 習志野市泉町 1-2-1

Nihon University, College of Industrial Technology

1-2-1, Izumicho, Narashino 275-8575
}

による雑音の小さな新しいプローブが開発されている ${ }^{(1) \text {-(9) }}$ が, 細管の保守検査においては，相対距離の変化による雑 音とさらに支持板による雑音の発生しないきず検出性能の より高いプローブが必要である。原子力発電プラントにお いては, 安全性の維持が極めて厳しいことから, コイルを 複数個配置してマルチ化した渦電流探傷プローブが開発さ れている。プローブをマルチ化することにより, きず検出 性能に優れているものの，プローブコストが高く，また既 存の探傷装置への適用が困難であり, 複雑な電子回路を備 えた専用の探傷装置を必要とする。

筆者らは, 従来のプローブの回転走査機構と既存の探傷 装置を利用できることも念頭に置き, 渦電流探傷試験にお ける試験導体に誘導される渦電流とコイル起電力について 考察を行い，きずによって新たに発生する渦電流を選択的 に検出して相対距離の変化による雑音と支持板による雑音 の発生しない新しい渦電流探傷プローブを提案する。きず によって新たに発生する渦電流を選択的に検出するので, 確実にきずを検出するために管に生じるきずの主な方向に 応じて構造が異なる 2 つプローブを考えた。すなわち， 管の軸方向に長さを持つきず（以下，軸方向きず）を確実 に検出するために管の周方向に渦電流を誘導しきずによっ て軸方向に発生する渦電流を軸方向に巻かれた検出コイル 
で検出するプローブと，管の周方向に長さを持つきず（以 下，周方向きず）を確実に検出するために軸方向に渦電流 を誘導しきずによって周方向に発生する渦電流を周方向に 巻かれた検出コイルで検出するプローブである。

プローブを製作して回転走査による渦電流探傷実験を行っ た結果, 従来のプローブで問題となっている相対距離の変 化による雑音と支持板による雑音とが原理的に発生せず, 支持板近傍のきずをも SN 比高く検出できることを確認し た。また，きずの深さや長さ，幅が異なる場合などについ て探傷実験を行い，プローブの基礎的なきず検出性能につ いて確認した。さらに，細管の保守検査では，漏洩事故を 未然に防ぐために，きずの哚さを知ることが重要である。 実験の結果，得られるきず信号の位相角がきず深さに応じ て変化するので，きず信号の位相角からきず深さの評価を 行えることを確認した。従来のプローブでは，きず信号の 振幅のみできず深さの評価を行っているが，信号振幅はき ずの長さや幅によっても変化するので，きず深さの評価に おいて精度が低いことが問題である。提案するプローブで は，きず信号の振幅と共に位相角を用いることによりきず 評価の精度向上が期待できる。

\section{2. 雑音の小さな渦電流探傷プローブ}

$\langle\mathbf{2} \cdot \mathbf{1}\rangle$ 誘導される渦電流とコイル起電力 電磁誘導 を利用した非破壞試験法である渦電流探傷試験は，交流を 流したコイル（以下，励磁コイル）によって試験導体に渦 電流を誘導し，きずなどの不連続部による渦電流の変化を 励磁コイルの起電力変化として, 或いは励磁コイルの近傍 に配置したコイル（以下，検出コイル）の起電力変化とし て検出し探傷を行う。そこで，励磁コイルによって試験導 体に誘導される渦電流とコイル起電力について考察する。

電磁誘導の法則に基ついて磁束密度 $B$ の変化により誘導 電界 $E$ は,

$$
\nabla \times E=-\partial B / \partial t
$$

となる。磁束密度 $B$ に対して磁気べクトルポテンシャル $A$ は，

$$
B=\nabla \times A
$$

と定義される。(1) 式と (2) 式から誘導電界 $E$ は, 電位勾配 の効果が小さい励磁コイルの近傍に㧍いては,

$$
E=-\partial A / \partial t
$$

である。

電流密度 $J$ の電流による誘導電界 $E$ によって導電率 $\sigma$ の 試験導体には渦電流 $J e$ が誘導される。

$$
J e=\sigma E=-\sigma(\partial A / \partial t)
$$

また，電流密度 $J$ にって発生する磁気ベクトルポテン シャル $A$ は，次式で与えられる(10)。

$$
A=\frac{\mu}{4 \pi} \iiint \frac{J}{r} d V c
$$

ここで, $\mu$ は透磁率, $r$ はコイルに流れる電流の密度 $J$ から 磁気ベクトルポテンシャル $A$ までの距離， $V c$ はコイル巻 線の体積である。試験導体に不連続部がなく電位勾配の効 果が小さい励磁コイルの近傍においては, (4) 式と (5) 式か ら渦電流 $J e$ は励磁コイルの電流 $J$ にほぼ平行なべクトル となる。したがって, 試験導体に不連続部が無い場合の励 磁コイルの近傍に扔ける渦電流は, 励磁コイルの巻線と基 本的に同じ方向に発生することとなる。筆者らは，有限要 素解析により試験導体に誘導される渦電流の流れについて 確認している。

巻数 $N$ の検出コイルの起電力 $V$ は，次式で与えられる。

$$
V=-N \frac{\partial}{\partial t}\left[\iint_{S} B \cdot n d S\right]=-N \frac{\partial}{\partial t}[\oint A \cdot d l] \cdots
$$

ここで, $S$ は検出コイルの面積, $n$ は微少面積 $d S$ に対する 単位法線ベクトル,$d l$ は検出コイルの巻線に沿った単位接 線ベクトルを表す。(5) 式より磁気ベクトルポテンシャル は，電位勾配の効果が小さい励磁コイル近傍に扔いては基 本的に電流と同じ向きのベクトルであるから, 励磁コイル の近傍に配置された検出コイルの各巻線部分は, その巻線 部分と平行な電流成分を検出することとなる。

$\langle\mathbf{2} \cdot \mathbf{2}\rangle$ 提案するプローブの考え方 前節 $\langle 2 \cdot 1\rangle$ の誘 導される渦電流とコイル起電力の考察に基づいて提案する プローブを考える。

従来のプローブでは，励磁コイルによって誘導される渦 電流それ自身の変化を検出して探傷を行う。渦電流は，き ず以外の相対距離の変化や支持板によっても変化するので, 従来のプローブでは, 相対距離の変化や支持板による雑音 を避けられない問題がある。筆者らは，励磁コイルによっ て誘導される渦電流それ自身の変化を検出するのではなく, きずによって新たに発生する渦電流のみを選択的に検出す る構造のプローブにすれば, 相対距離の変化による雑音と 支持板による雑音が発生せず，SN 比高くきず検出を行え ると考えた。

誘導される渦電流の向きが割れきずの方向と平行である 場合にはきずによって発生する渦電流は小さいが，きずと 直交するように渦電流を誘導すれば，きずに沿って流れる 新たな渦電流が発生する。したがって，励磁コイルはきず と直交するように配置する。また，(6) 式より検出コイル 起電力は検出コイルの卷線部分と平行な電流成分によって 発生するから，きずに沿って新に発生した渦電流を検出す るために検出コイルはきずと平行に配置する。この様な考 えに基づき, 雑音を発生せずきずを確実に検出するために,

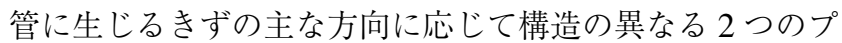
ローブを提案する。

〈2·3〉 軸方向きずを検出するプローブ＼cjkstart管の軸方向 に長さを持つきずを検出するために図 1 の構造のプローブ （以下，軸方向プローブ）を提案する。図 (a) は正面図，図 


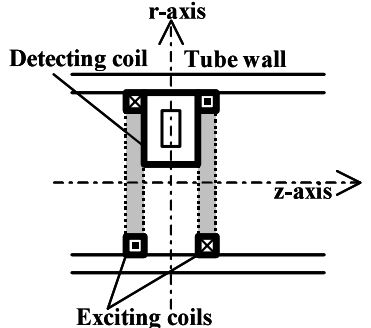

(a) Front view

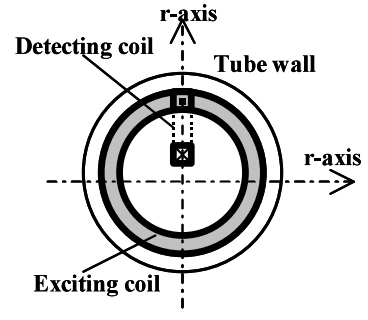

(b) Side view
図 1 軸方向プローブの構造

Fig. 1. New eddy current probe for detection of axial flaws (new axial flaw detection probe).

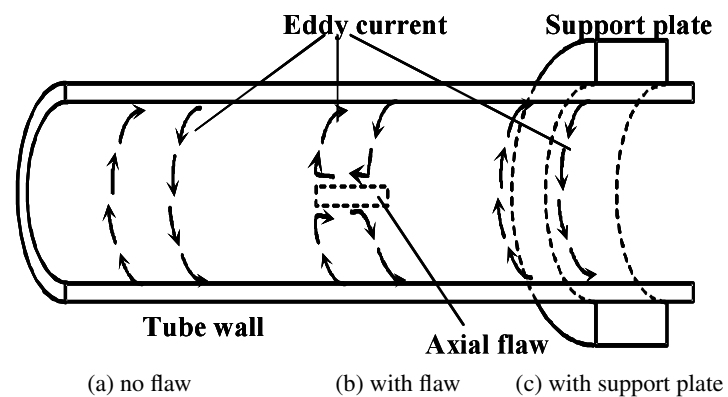

図 2 軸方向プローブのきず検出原理

Fig. 2. Principle of flaw detection by the new axial flaw detection probe.

(b) は側面図を表す。軸方向プローブは，管の周方向に巻か れた円形の 2 つの励磁コイルとその間に置かれ軸方向に巻 かれた矩形の検出コイルから構成される。検出コイルの径 方向の長さは, 励磁コイルの外径の半分以下である。

図 2 には，管表面に誘導される渦電流を示す。2つの励 磁コイルに逆向きの交流を流すと，図 2(a) に示すようにき ずなどの不連続部がない場合には, $2 \cdot 1>$ 節で述べた様に 励磁コイルの巻線方向である管周方向にのみ渦電流が誘導 され，検出コイルの巻線方向である管軸方向の渦電流成分 はない。(6) 式より検出コイルはそれ自身の巻線方向と平行 な電流成分を検出するから，きずなどの不連続部がない場 合には，検出コイルの巻線方向に渦電流成分が存在しない ので起電力は発生しない。プローブと管との相対距離が変 化しても，励磁コイルによって誘導される渦電流の大きさ は変化するが，プローブが管の中心軸に対して傾かない限 りは, 検出コイルの巻線方向には渦電流は流れないの起電 力が生じず，従来のプローブで問題となっている相対距離 の変化による雑音が原理的に発生しない。

図 2(b) に示すように軸方向にきずがある場合には，誘導 される渦電流の一部がきず長さ方向に沿って軸方向に流れ る。検出コイルは軸方向に巻かれているから，きずに沿っ て軸方向に流れた渦電流によって起電力が発生し，きずの 検出が行える。きずに沿って流れる渦電流はきずの両側で 流れる向きが逆であるので，プローブが周方向に回転する ときずの前後で極性の異なる信号が得られる。

図 2(c) に示すように支持板近傍に励磁コイルが位置して

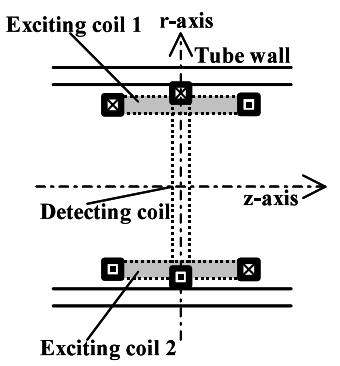

(a) Front view

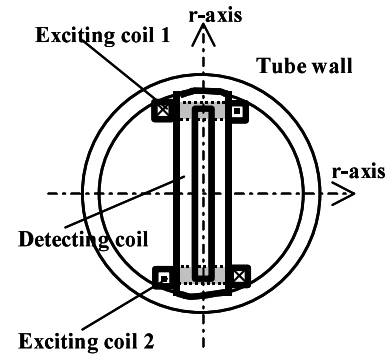

(b) Side view
図 3 周方向プローブの構造

Fig. 3. New eddy current probe for detection of circumferential flaws (new circumferential flaw detection probe).

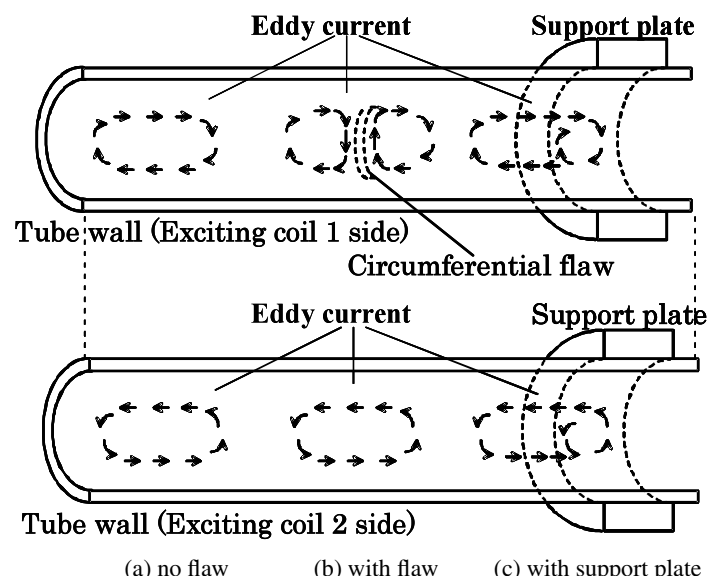

図 4 周方向プローブのきず検出原理

Fig. 4. Principle of flaw detection by the new circumferential flaw detection probe.

も，周方向に巻かれた $2 つ の$ 励磁コイルや試験導体である 管及び支持板等が軸対称の配置である限りは，渦電流は励 磁コイル巻線方向に流れ, 検出コイルの巻線方向には流れ ないので，支持板による雑音は原理的に発生しない。支持 板の近傍に軸方向のきずがある場合には，支持板による雑 音が発生しないから, 従来のプローブに比べて SN 比高く きず検出が行える。

〈2・4〉 周方向のきずを検出するプローブ 管の周方 向に長さを持つきずを検出するために図 3 の構造のプロー ブ（周方向プローブ）を提案する。図 (a) は正面図, 図 (b) は側面図を表す。周方向プローブは, 管内表面に平行に置 かれ軸方向に長辺を持つ矩形に巻かれた 2 つの励磁コイル と周方向に巻かれた矩形の検出コイルから構成される。2 つの励磁コイルは相対して配置してあり, 検出コイルは励 磁コイルの中央に配置されている。

図 4 には管に誘導される渦電流を示す。きずなどの不連 続部がない場合には，〈2・1〉節で述べた様に図 4(a)に示す ように励磁コイル 1 側と 2 側共に励磁コイルの巻線方向に 渦電流が誘導され, 検出コイルが位置する励磁コイルの中 央部分では周方向には渦電流が流れない。(6) 式より検出コ イルはそれ自身の巻線方向と平行な電流成分を検出するか 


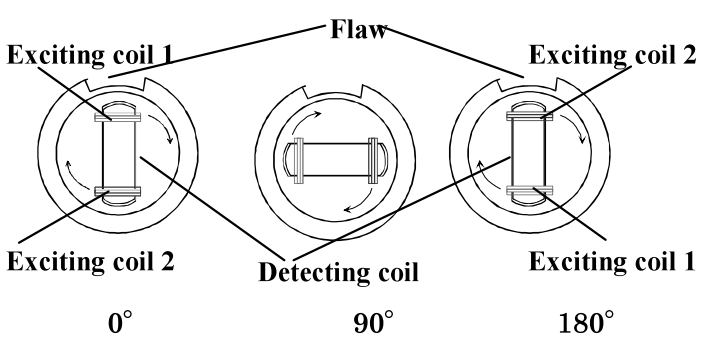

図 5 周方向プローブを回転走査したときのきず検出

Fig. 5. Circumferential flaw detecting image of the new circumferential flaw detection probe.

ら，きずなどの不連続部がない場合には，起電力は発生し ない。プローブと管との相対距離が変化しても，プローブ が管表面に対して傾かない限りは，検出コイルの巻線方向 には渦電流が流れないので, 起電力が生じず，相対距離の 変化による雑音が原理的に発生しない。

図 4(b) に示すように励磁コイル 1 側に周方向にきずがあ る場合には，誘導される渦電流の一部がきずの長さ方向に 沿って周方向にも流れる。検出コイルは周方向に巻かれて いるから，きずに沿って周方向に流れた渦電流によって起 電力が発生し，きず検出が行える。きずに沿って周方向に 流れる渦電流はきずの両側で流れる向きが逆であるので, プローブが軸方向に移動するときずの前後で極性の異なる 信号となる。さらに，周方向プローブの場合には，プロー ブが周方向に回転すると図 5 に示すようにきずを励磁コイ ル 1 と励磁コイル 2 が通過するので，極性の異なるきず信 号が発生する。

図 4(c) に示すように支持板近傍に励磁コイルが位置する と支持板に沿って励磁コイル 1 側と 2 側共に周方向に渦電 流が流れ，検出コイルは周方向の渦電流を検出することと なるが，励磁コイル 1 に打ける検出コイルの巻線方向と励 磁コイル 2 に扔ける検出コイルの巻線方向とは逆向きであ るので, (6) 式より起電力は相殺し, 支持板による雑音は原 理的に発生しない。支持板の近傍で励磁コイル 1 に周方向 のきずがある場合には，励磁コイル 1 における周方向に発 生する渦電流と励磁コイル 2 における周方向に発生する渦 電流とは異なるから，支持板近傍のきずを検出できる。以 上の様に相対距離の変化による雑音と支持板による雑音が 原理的に発生しないから $\mathrm{SN}$ 比高くきず検出が行える。

筆者らは，有限要素解析により試験導体に誘導される渦 電流の流れについて確認した。図 6 にスリット状きずのあ る平板導体に矩形の励磁コイルが相対して配置したときの 導体表面に誘導される渦電流の流れを示す。渦電流の流れ の向きを矢印の方向で，渦電流の大きさを矢印の大きさで 示す。図より励磁コイル近傍においてコイル巻線方向に渦 電流が誘導され，またきず近傍ではきずに沿って流れる渦 電流を確認できる。

\section{3. 実験方法}

実験に用いた軸方向プローブの励磁コイルの寸法は，外

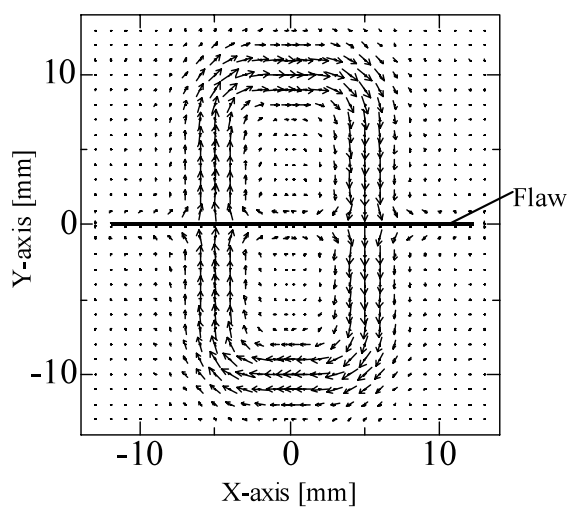

図 6 矩形コイルによってきずのある試験体に 誘導される渦電流

Fig. 6. Eddy current distribution in conducting plate with slit flaw by a rectangular coil.

径 $18 \mathrm{~mm}$, 巻線断面積 $2 \times 2 \mathrm{~mm}^{2}$ であり, 検出コイル寸法は, 軸方向に長さ $4 \mathrm{~mm}$, 径方向に $7 \mathrm{~mm}$, 卷線断面積 $1 \times 1 \mathrm{~mm}^{2}$ である。検出コイルの軸方向長さが $4 \mathrm{~mm}$ で励磁コイルの 巻線幅が $2 \mathrm{~mm}$ であるのでプローブの軸方向幅は $8 \mathrm{~mm}$ と なる。また，周方向プローブの励磁コイルの寸法は，軸方 向に長さ $25 \mathrm{~mm}$, 周方向に $8 \mathrm{~mm}$, 巻線断面積 $2 \times 2 \mathrm{~mm}^{2}$ で あり, 検出コイルの寸法は, 周方向に長さ $4 \mathrm{~mm}$, 径方向に $18 \mathrm{~mm}$, 巻線断面積 $1 \times 1 \mathrm{~mm}^{2}$ である。検出コイルは励磁コ イル内側に位置し, 励磁コイルの周方向長さが $8 \mathrm{~mm}$ であ るのでプローブの周方向幅は $8 \mathrm{~mm}$ となる。

試験体としては, 外径 $21 \mathrm{~mm}$, 管肉厚 $1.5 \mathrm{~mm}$ の黄銅管を 細管として, またドーナッツ状の外径 $61 \mathrm{~mm}$, 厚さ $20 \mathrm{~mm}$, 幅 $15 \mathrm{~mm}$ の鋼材を支持板として用いた。黄銅管の外面には 軸方向及び周方向に長さ $5,10,15,25 \mathrm{~mm}$ で深さを管肉 厚に対して $100 \% ， 80 \% ， 60 \% ， 40 \%$ ，幅 0.2，0.5，0.8 mm のスリットをそれぞれ放電加工してきずとした。軸方向に 長さのあるスリットを軸方向きずとし，周方向に長さのあ るスリットを周方向きずとする。

実験を種々の試験周波数で行ったが，本実験で使用した 試験体に対する渦電流の浸透深さから，試験体の外面きず を感度良く検出できた $9 \mathrm{kHz}$ の試験周波数とした。渦電流 探傷試験では, 試験周波数を高くすると渦電流の浸透深さ が浅くなり外面きずの信号が小さくなる。また, 試験周波 数を低くするときず信号位相の変化の割合が小さくなるの で, 試験体每に適切な試験周波数を設定して検査を行ってい る。プローブと試験体との相対距離を $0.5 \mathrm{~mm}$ とした。管 内部に挿入したプローブを周方向に 1 回転させた後，軸方 向に $0.5 \mathrm{~mm}$ 移動することを繰返して管内表面において 2 次元に回転走査した。きずが単独にある場合や支持板近傍 にきずがある場合などについて探傷実験を行った。支持板 ときずとの位置関係例を図 7 に示す。

また，きず検出性能の比較のために，外径 $6 \mathrm{~mm}$, 巻線断 面積 $1 \times 1 \mathrm{~mm}^{2}$ の円形コイルを従来の渦電流探傷プローブと して用い探傷実験を行った。 


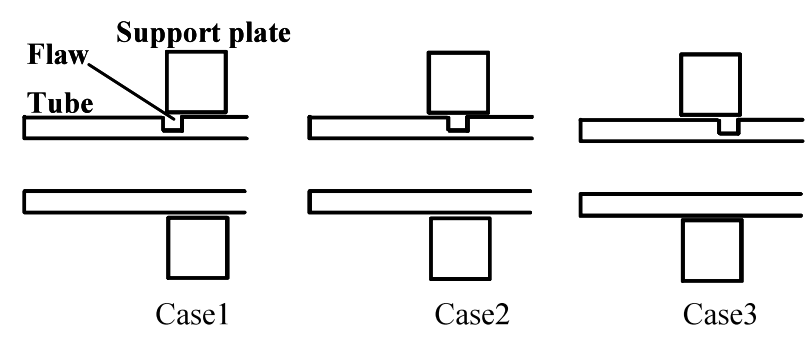

図 7 支持板下におけるきず位置

Fig. 7. Flaw position under the support plate.

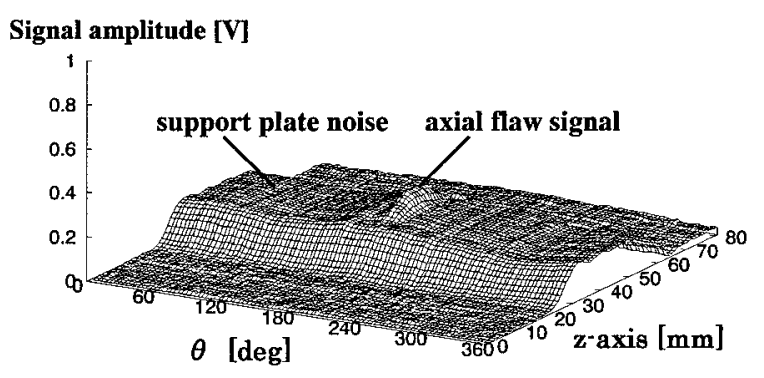

Flaw : depth $60 \%$, length $15 \mathrm{~mm}$, width $0.5 \mathrm{~mm}$

図 8 従来のプローブによる渦電流探傷信号

Fig. 8. Eddy current flaw signal by the conventional probe.

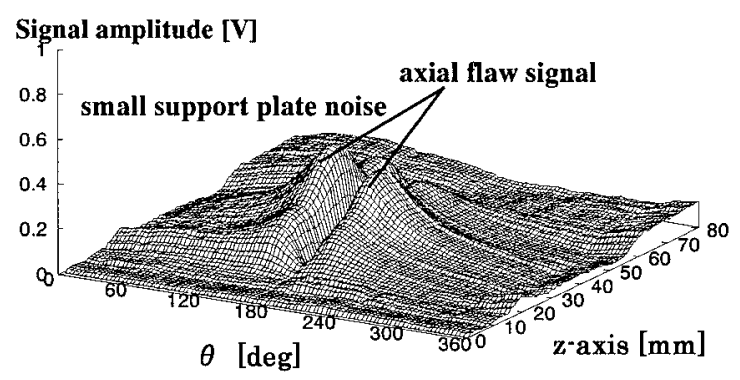

Flaw : depth $60 \%$, length $15 \mathrm{~mm}$, width $0.5 \mathrm{~mm}$

図 9 軸方向プローブによる渦電流探傷信号

Fig. 9. Eddy current flaw signal by the new axial flaw detection probe.

\section{4. 実験結果}

$\langle\mathbf{4} \cdot \mathbf{1}\rangle$ 支持板近傍の探傷結果 支持板近傍の管外面に 深さ $60 \%$ のきすがある場合について, プローブを管内表面に おいて 2 次元に回転走查したときの渦電流探傷結果を示す。 図 8 には，従来のプローブによる探傷結果を示す。渦電流 探傷信号は，励磁コイルの電流に対して同相成分 (In-phase component）と 90 度進相成分（Quadrature component）の 複素信号で得られるが，図では信号の振幅で表した。また， 図中の $\mathrm{z}$-axis は管の軸方向を, $\theta$ は管の周方向を示す。渦電 流それ自身の変化を検出する従来のプローブでは，支持板 によって渦電流の流れが変化するため，支持板による大き な雑音が発生し, 明膫なきず信号が得られていない。この ために，支持板近傍のきず検出が困難であることがわかる。 一方，図 9 に示す軸方向プローブと図 10 に示す周方向プ

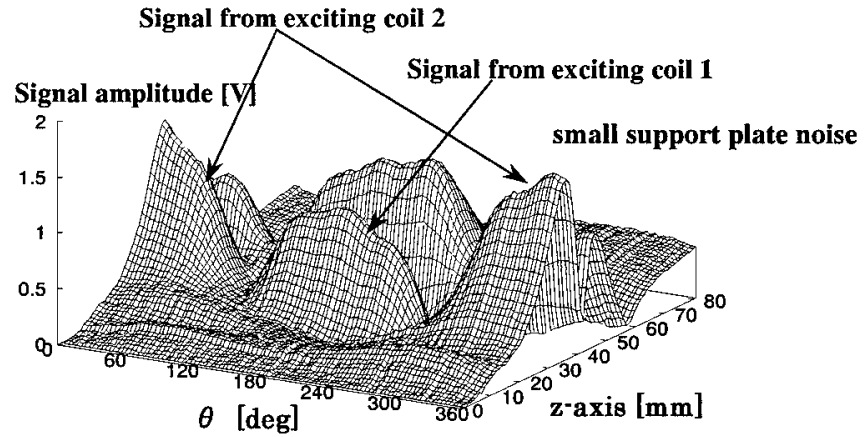

Flaw : depth $60 \%$, length $15 \mathrm{~mm}$, width $0.5 \mathrm{~mm}$

図 10 周方向プローブによる渦電流探傷信号

Fig. 10. Eddy current flaw signal by the new circumferential flaw detection probe.

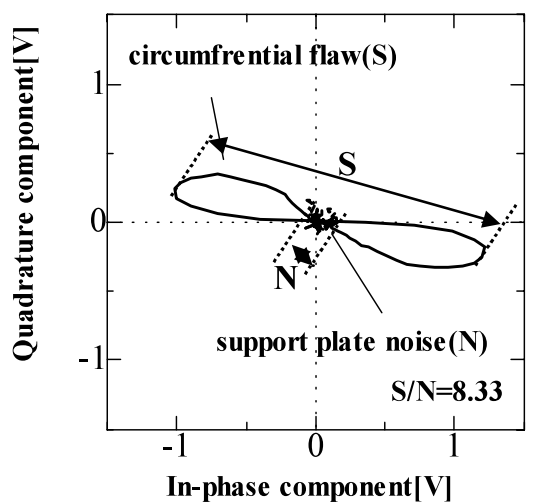

図 11 周方向プローブにおける支持板雑音と きず信号

Fig. 11. Support plate noise and flaw signal obtained by the new circumferential flaw detection probe.

ローブの場合には，支持板による雑音が非常に小さく，明 瞭なきず信号が得られている。すなわち, 支持板近傍のき ずを雑音小さく検出できることがわかる。両プローブ共に プローブの走査によって極性の異なる信号を得るが，図に

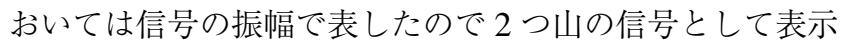
されている。更に，周方向プローブでは，プローブの回転 走査によって励磁コイル 1 と 2 がきずを通過するため，き ず信号が 2 回発生するので 4 つ山の信号として表示されて いる。

きずがない位置においてプローブを回転走査して発生す る支持板による雑音（N）の最大振幅ときずの上を回転走 査して得られるきず信号（S）の振幅との比を各プローブ について求めた。図 11 に例として周方向プローブにおけ る支持板雑音ときず信号との軌跡を複素平面上に示す。図 中の支持板雑音 $(\mathrm{N})$ ときず信号 $(\mathrm{S})$ とより $\mathrm{SN}$ 比を求め た。従来のプローブの SN 比は 1.2 であったのに対して軸 方向プローブでは 7.5, 周方向プローブでは 8.3 と非常に高 い SN 比を得られた。提案するプローブは, SN 比高く支持 板近傍のきず検出が行えることがわかる。

〈4・2〉基礎的なきず検出特性きずの深さや長さ，幅 


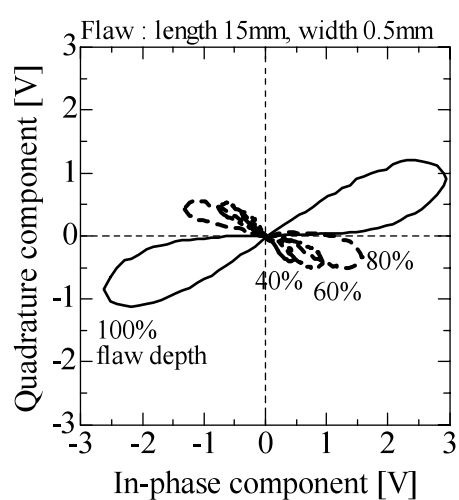

図 12 きず深さが異なる場合のきず信号

Fig. 12. Flaw signals for different flaw depths.

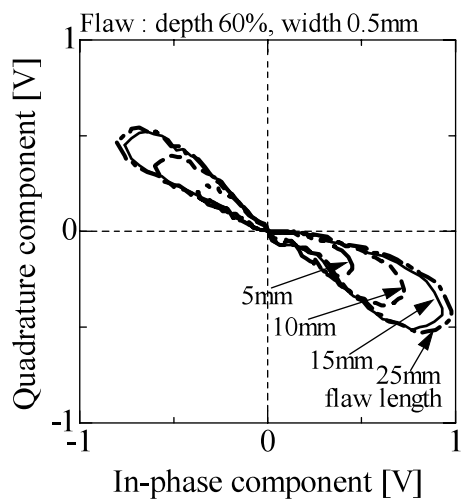

図 13 きず長さが異なる場合のきず信号

Fig. 13. Flaw signals for different flaw lengths.

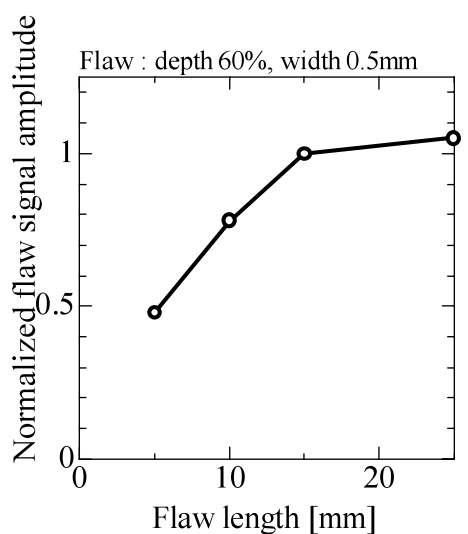

図 14 きず長さに対するきず信号振幅の変化

Fig. 14. Flaw signals amplitude vs. flaw length.

などが異なる場合について探傷実験を行い，プローブの基 礎的なきず検出特性の確認を行った。図 12 には，きずが 単独にある場合において，長さと幅は同じで深さの異なる きずに対して軸方向プローブを走査して得られたきず信号 を複素平面上に示す。きず深さが浅くなると信号振幅は小 さくなるものの深さ $40 \%$ の外面きずをも検出できているこ とがわかる。また，きず深さに応じて信号位相が変化して いることがわかる。

図 13 には，深さと幅は同じで長さの異なるきずに対し

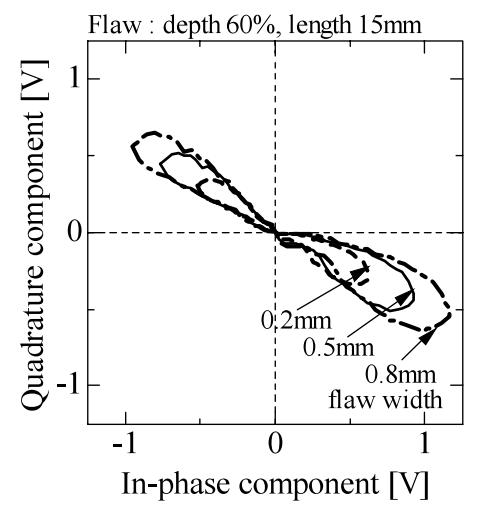

図 15 きず幅が異なる場合のきず信号

Fig. 15. Flaw signals for different flaw widths.

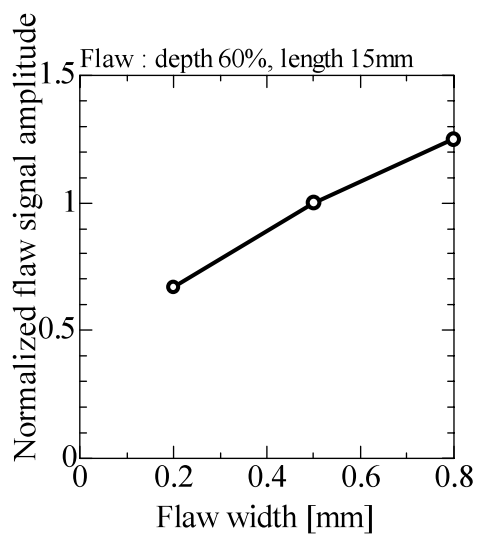

図 16 きず幅に対するきず信号振幅の変化

Fig. 16. Flaw signals amplitude vs. flaw width.

て軸方向プローブを走査して得られたきず信号を複素平面 上に示す。図 14 には，きず長さ $15 \mathrm{~mm}$ のきず信号振幅で 正規化したときのきず長さに対するきず信号振幅の変化を 示す。プローブの軸方向幅 $8 \mathrm{~mm}$ より十分に長いきずに対 してはきず信号振幅がほぼ同じであり同感度できず検出を 行えるが，きず長さが短くなるときず信号振幅が小さくな ることがわかる。これはきずが短くなるときずに沿って流 れる渦電流が小さくなるためである。一方，きず信号振幅 はきず長さで変化するが，きず信号の位相角は，きず長さ によらずほぼ一定であることがわかる。

四 15 には，深さと長さは同じで幅の異なるきずに対し て軸方向プローブを走査して得られたきず信号を複素平面 上に示す。図 16 には，きず幅 $0.5 \mathrm{~mm}$ のきず信号振幅で正 規化したときのきず幅に対するきず信号振幅の変化を示す。 きず幅が狭くなるときず信号振幅が小さくなるものの，き ず信号の位相角は，きず幅によらずほぼ一定であることが わかる。周方向プローブについても同様な結果が得られる ことを確認している。

これらの結果よりきず信号の位相角は，きず深さに応じ て変化しきずの長さや幅などに対しては変化しないことが わかる。すなわち，きず信号の位相角よりきず深さの評価 を行えることが期待できる。 
Flaw: depth $60 \%$, length $15 \mathrm{~mm}$, width $0.5 \mathrm{~mm}$

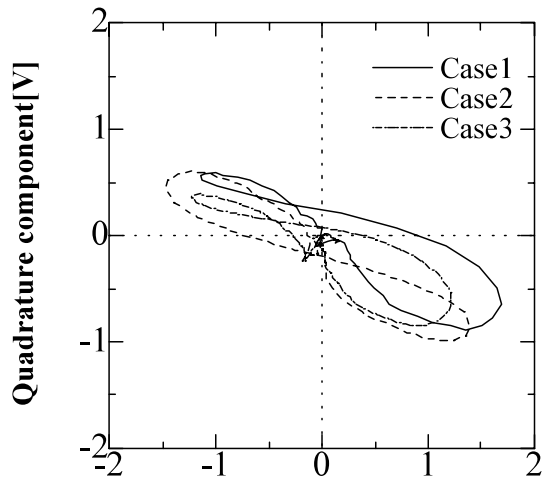

In-phase component[V]

(a) the new axial flaw detection probe

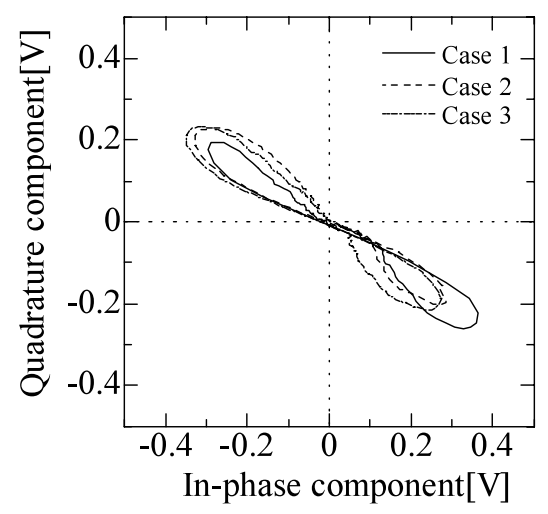

(b) the new circumferential flaw detection probe

図 17 支持板近傍のきずによる信号

Fig. 17. Flaw signal for flaw placed under the support plate.

〈4·3〉きず深さの評価＼cjkstart細管の保守検査においては， 漏洩事故を防ぐために，きず深さを知ることが重要である。 渦電流探傷試験では，複素平面上におけるきず信号の傾き 角度である信号位相からきず深さの評価が行われている(11)。

図 17 には, きずの深さ $60 \%$ で図 7 に示した支持板に対す るきず位置が異なる場合について, 図 (a) に軸方向プローブ 及び図 (b) に周方向プローブを走査して得られたきず信号 を表す。支持板に対するきずの位置が異なるときず信号の 軌跡は支持板による影響で変化するが，きず深さが同じで あれば信号位相はほぼ同じであることがわかる。したがっ て，きずが単独にある場合や支持板近傍にある場合とによ らず，きず信号の位相角からきず深さの評価を行えること が期待できる。

図 18 には，深さ $100 \%$ のずによる信号の位相角を $0 \mathrm{deg}$ として，きず深さに対する信号の位相の変化を示す。きず が単独に存在する場合だけでなく支持板近傍にきずが存在 する場合でも，きず深さに応じて信号の位相が変化するこ とがわかる。従来のプローブでは，同じ深さのきずでも相 対距離の変化による雑音や支持板による雑音のため信号位 相が変化するので，信号の振幅に基づいてきずの評価が行 われている。しかし，信号の振幅は，きずの深さだけでな

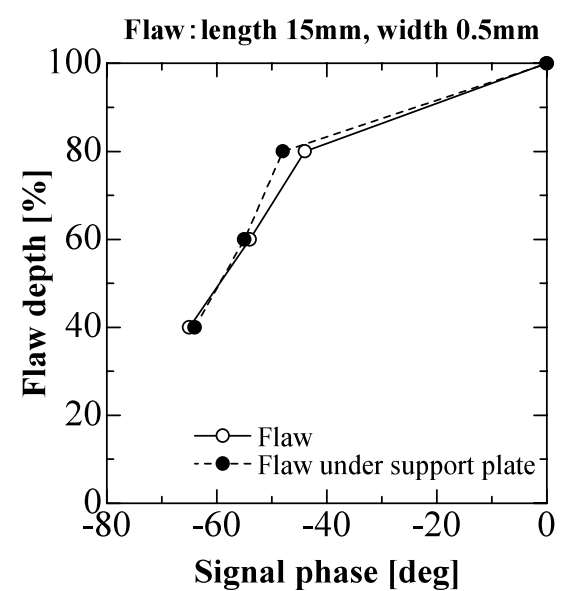

図 18 きず信号位相によるきず深さの評価

Fig. 18. Flaw depth estimation according to the flaw signal phase.

く長さや幅で変化するので正確なきず深さの評価が困難で あるのが現状である。これに対して，提案するプローブで は，信号の振幅と共に位相を用いることによりきず深さ評 価の精度を向上できると考える。周方向プローブについて も同様な結果が得られ, きず深さに応じて信号位相が変化 することを確認している。

\section{5. おわりに}

熱交換器などで使用されている細管の渦電流探傷試験に おけるきず検出性能の向上を志向して, 雑音の小さな渦電 流探傷プローブを提案した。提案したプローブのきず検出 特性について検討し，以下の知見を得た。

（1）提案する渦電流探傷プローブは，プローブと試験 導体との相対距離の変化による雑音や支持板による雑音が, 従来のプローブに比べて非常に小さい。

（2）従って，支持板近傍の小さなきずも SN 比高く検 出できる見通しを得た。

（3）支持板に対するきずの相対位置の違いによりきず信 号の軌跡は異なるが，きず信号の位相角はほぼ変化しない。

（4）また，支持板の有無によらずきず深さに応じてき ず信号の位相が変化する。

（５）きず信号の振幅はきず長さや幅で変化するが，き ず信号の位相角はきず深さが同じであればほぼ変化しない。

（6）従って，きず信号の位相に基づいてきず深さの評 価を行えると期待できる。

（7）プローブの幅より十分に長いきずに対してはきず 長さによらずにほぼ同じ信号振幅を得られるが，プローブ 幅より短いきずに対してはきずに沿って流れる渦電流が小 さくなるのできず信号振幅が小さくなる。

（8）軸方向プローブと周方向プローブとを 1 組として 管内表面を周方向への回転と軸方向への移動を繰り返す回 転走査を一度行えば，軸方向及び周方向のきずを同時に探 傷可能であると考える。 
今回はプローブ寸法などを一定として検討を行ったが， 今後プローブ寸法のきず検出性能に与える影響や磁性体の 管の場合など更なる検討を行う予定である。

(平成 17 年 8 月 31 日受付, 平成 18 年 2 月 28 日再受付)

\section{文献}

(1) B. Wincheski, J.P. Fulton, S. Nath, M. Namkung, and J.W. Simpson: "Selfnulling Eddy Current Probe for Surface and Subsurface Flaw Detection", Materials Evaluation, Vol.52, No.1, pp.22-26 (1994)

(2) K. Krzywosz: "Latest Eddy Current Applications in Nuclear Industry", 13th International Conf. Nuclear \& Pressuer Vessel Industries Kyoto Japan, pp.61-65 (1995)

(3) H. Hoshikawa and K. Koyama: "Eddy Current Testing Probe using Rotating Direction Eddy Current", Journal of The Japan Society of Applied Electromagnetic and Mechanics, Vol.3, No.3, pp.36-42 (1995) (in Japanese) 星川 洋・小山 潔:「回転渦電流を利用した渦流探傷プローブ」, 日 本 AEM 学会論文誌, 3, 3, pp.36-42 (1995)

(4) G.L. Burkhardt, J.L. Fisher, J.S. Stolte, S.R. Kramer, and K.L. Cobble: "NDE of Aging Aircraft Structure using Orthogonal-axis Eddy Current Probes", Review of Progress in QNDE, Vol.16, pp.1021-1027 (1997)

(5) H. Hoshikawa and K. Koyama: "A New Eddy Current Probe using Uniform Rotating Eddy Currents", Materials Evaluation, Vol.56, No.1, pp.8589 (1998)

(6) K. Koyama and H. Hoshikawa: "Fundamental Characteristics of Uniform Eddy Current Probe in ECT", Journal of the Japanese Society for NonDestructive Inspection, Vol.49, No.11, pp.775-781 (2000) (in Japanese) 小山 潔・星川 洋：「渦流探傷試験における一様渦電流プローブ の基礎的特性に関する研究」, 非破壊検査, 49, 11, pp.775-781 (2000)

(7) H. Hoshikawa, K. Koyama, and H. Karasawa: "Study of a New Surface Eddy Current Probe without Lift-off Noise", Journal of the Japanese Society for Non-Destructive Inspection, Vol.50, No.11, pp.736-742 (2001) (in Japanese)

星川 洋・小山 潔・柄沢英之：「リフトオフ雑音が発生しない渦 流探傷用上置プローブに関する研究」, 非破壞検査, 50, 11, pp.736-742 (2001)

(8) H. Hoshikawa and K. Koyama: "A New Eddy Current Probe with Minimal Liftoff Noise and Phase Information on Discontinuity Depth", Materials Evaluation, Vol.61, No.3, pp.423-427 (2003)

(9) H. Hoshikawa and K. Koyama: "Proposition for a New Eddy Current Probe for Flaw Depth Evaluation with Minimal Lift-off Noise", Journal of the Japanese Society for Non-Destructive Inspection, Vol.53, No.5, pp.288-293 (2004) (in Japanese)

星川 洋，小山 潔：「きず深さの評価を目指したリフトオフ雑音が 小さい渦流探傷上置プローブの提案」, 非破壊検査, 53, 5, pp.288-293 (2004)

(10) For Example, N. Kumagai: Electromagnetic Theory, Corona Publishing Co., Ltd. (1991) (in Japanese)

例えば, 熊谷信昭：「電磁理論」,コロナ社 (1991)

(11) ASME Boiler \& Pressure Vessel Code, Sec. V Article 8 (1978 Winter Addenda)

星 川 洋（正員） 1942 年 7 月 21 日生。1965 年 3 月山形

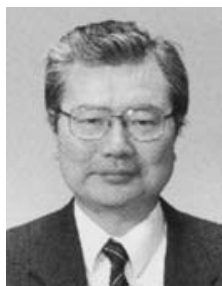
大学卒業。1967 年 3 月山形大学大学院修士課程 修了。同年 4 月より日本大学生産工学部に勤務。 1989 年 4 月同教授。現在は主として渦電流探傷 に関する研究に従事。工学博士。

小山

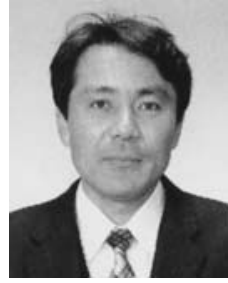

潔（正員） 1963 年 3 月 24 日生。1986 年 3 月日本 大学卒業。1988 年 3 月日本大学大学院博士前期 課程修了。1991 年 1 月より日本大学生産工学部 に勤務。2001 年 4 月同助教授。現在は電磁気の 応用計測に関する研究に従事。博士（工学）。 